\title{
The Use of an Arginine-Enriched Oral Nutrition Supplement to Enhance Wound Healing from a Cesarean Section
}

\author{
Kristen Hicks-Roof \\ Department of Nutrition and Dietetics, University of North Florida, Jacksonville, FL, USA
}

\section{Keywords}

Cesarean section · Enteral nutrition · Lifestyle $\cdot$ Pregnancy $\cdot$ Wound healing

\begin{abstract}
Background: Surgical wounds can directly hinder daily activities and leave scars that can have long-term impacts on a patient. Cesarean sections account for over one-third of all baby deliveries, resulting in women faced with a wound needing rapid healing to take care of their baby. Case Presentation: The patient received an arginine-enriched oral nutrition supplement twice daily for 14 days as a therapeutic intervention to aid in wound healing and recovery. At the 2-week postpartum visit, validated scar assessment scales were completed to determine how the surgical wound was healing. It was shown that this therapeutic intervention improved wound healing as indicated by low scar assessments. Conclusion: This woman showed that consuming an arginine-enriched oral nutrition supplement could optimize healing following a cesarean section. Future research needs to be conducted on a larger sample size to determine whether these results can be generalized to the broader population.
\end{abstract}




\section{Case Reports in Clinical Nutrition}

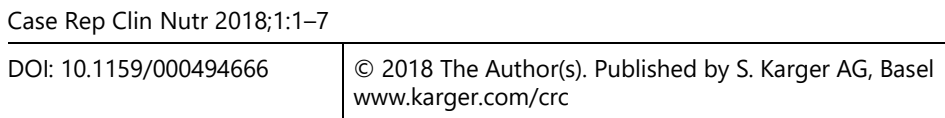

Hicks-Roof: Arginine-Enriched Oral Nutrition Supplement for Wound Healing

\section{Introduction}

Wound healing is a complex bodily process which requires specific nutrients to promote the healing process and repair the tissue. Optimal wound healing demands that a person consume adequate nutrition, as nutrient deficiencies have shown a delay in the healing process and potential for infections [1,2]. Malnutrition and micronutrient deficiencies can negatively affect wound healing due to the missing building blocks for tissue repair [3]. The main goal for adequate wound healing is to optimize recovery in the shortest time, with minimal discomfort, scarring, and pain for the patient [4]. Protein and carbohydrates are the main macronutrients needed to stimulate tissue synthesis. High-protein diets have been show to aid in healing of pressure ulcers and other open wounds $[5,6]$. Some nutrients in particular that have been shown to enhance the healing process include vitamin C, vitamin E, zinc, and two important amino acids, arginine and glutamine [7, 8]. Research has shown that arginine, vitamin C, and zinc may be among the most important nutrients to promote wound healing. Arginine is a conditionally essential amino acid that, when used as a therapeutic intervention, has been shown to decrease infections after major surgeries $[9,10]$. Glutamine is one of the most abundant amino acids and is essential under stressful conditions to improve nitrogen balance and target oxidative stress [3].

In the dietetics realm, oral nutritional supplements are often used to aid in wound healing. Commonly seen in the clinical setting for wound healing are the three main arginine-enriched beverages: Resource Arginaid ${ }^{\odot}$ (Novartis Nutrition, Minneapolis, MN, USA), Juven/Abound ${ }^{\odot}$ (Abbott Nutrition, Columbus, OH, USA), and Cubitan ${ }^{\circledR}$ (Nutricia, Gaithersburg, MD, USA). Numerous studies support the notion that high-protein, arginine, and micronutrient oral nutrition supplements promote improved pressure ulcer healing [11-14].

Although arginine-enriched oral nutrition supplements have been shown to be effective for pressure ulcer wound healing, they may be optimal sources of nutrition for other types of wound healing as well. In the United States, approximately 1,258,581 (31.9\%) of all births are delivered via cesarean section [15]. Cesarean section has been documented as the most common operation in operating rooms across US hospitals [16]. This procedure overall has nearly $50 \%$ higher costs for both maternal and newborn care compared to vaginal birth [17]. In addition to the increased cost, the minimum recovery period is significantly longer for a cesarean than a vaginal birth ( 6 vs. 2 weeks). Women have reported pain, decreased mobility, abdominal wound issues, and concerns of infection when giving birth via cesarean section [18]. This case report examines the impact of consuming an arginine-enriched oral nutrition supplement on surgical wound healing from a cesarean section.

\section{Case Presentation}

The patient was a 28-year-old female who was considered to be in a healthy BMI range before pregnancy. She had no past medical history of any chronic illnesses. Table 1 presents anthropometric measurements from pre-pregnancy to 2 weeks postpartum to indicate the health of the patient. At 32 weeks, the patient discovered that her baby was in the frank breech position. At 36 weeks, the patient had a failed version attempt; therefore, to ensure the safety 
of both mother and baby, she elected for a scheduled cesarean section. In this cesarean section, the patient's wound was closed by the use of sutures.

The patient consumed an overall healthy diet which regularly consisted of 2-5 servings each of fruit, vegetables, whole grains, protein, and dairy. No dietary records were collected during the writing of this case report. On top of the standard dietary intake, an arginineenriched oral nutrition supplement was consumed daily to promote wound healing. The nutritional intervention is a popular oral supplement which provides $90 \mathrm{kcal}, 7 \mathrm{~g}$ of L-arginine, $7 \mathrm{~g}$ of L-glutamine, $2.5 \mathrm{~g}$ of collagen protein, $300 \mathrm{mg}$ of vitamin C, $15 \mathrm{mg}$ of vitamin E, $9.5 \mathrm{mg}$ of zinc, and $1.5 \mathrm{~g}$ of $\beta$-hydroxy- $\beta$-methylbutyrate (Juven $\odot$, Abbott Nutrition). Twice daily for 14 days, a packet of Juven ${ }^{\odot}$ powder was dissolved in $500-1,000 \mathrm{~mL}$ of water and consumed.

\section{Results}

Cesarean section is considered to be a major surgery, which results in a horizontal scar on the lower abdomen. Rapid healing of surgical wounds has the potential to play a significant role in decreasing hospitalizations and more rapid return to daily function [19]. At her 2-week postpartum follow-up visit, the obstetrician performed a scar evaluation using the Stony Brook Scar Evaluation Scale (Table 2) and the Manchester Scar Scale (Table 3). These two assessment scales were selected due to their assessment in the short term of scars and applicability to a wide range of scars [20]. Assessment measures showed that the scar had been healing properly as indicated by low scar assessment values. An image was captured 2 weeks postpartum to provide a visual scar assessment (Fig. 1). In addition, when the obstetrician was asked, "How does this scar compare to other postpartum patients at this practice who had a cesarean section?" she responded, "It appears to be healing better than most patients." The patient was ambulatory at day 2 postpartum and was reported to be feeling that she was recovering quickly. Qualitative assessment from the patient indicated that she had nominal discomfort and had an optimal recovery from her cesarean section due to the arginine-enriched oral nutrition supplement.

\section{Discussion and Conclusion}

Women who undergo a cesarean section face many barriers that hinder their recovery. It is crucial for a woman to recover quickly in order to take care of her newborn baby, to prevent rehospitalization, and to get back to everyday activities. In this case report, the use of an arginine-enriched oral nutrition supplement has been shown to improve healing of the surgical wound. Both the Stony Brook Scar Evaluation Scale and the Manchester Scar Scale have been used to assess the physical characteristics and esthetics of scars [21]. Both scales include components of the visual analog scale in addition to more attributes analyzed [20]. The Stony Brook Scar Evaluation Scale has been validated for other surgical incisions, with a total score of 5 indicating "best possible scar" on the visual cosmetic scale [22]. A large prospective trial used the same scar scale and found that a suture skin closure method resulted in only $16 \%$ of all women having a score of 5; moreover, a majority of women (67\%) had a score of 3 or less [23]. A low score of 8 out of possible 18 on the Manchester Scar Scale as a subjective scar 
assessment indicates optimal healing [24]. While these oral nutrition supplements are regularly used for pressure ulcer healing, similar wound healing mechanisms take place recovering from surgical wounds.

As this is just one case, the findings cannot be assumed to improve wound healing for all cesarean section patients. Additionally, this patient was a healthy female who consumed what is considered a healthy diet. While limitations are clearly present, this is an opportunity to enhance recovery of women around the world who undergo a cesarean section. More research needs to be conducted with women of different body types, ages, and dietary intakes to determine whether these findings are applicable to the generalizable population. This case report is an important example of how therapeutic nutrition can play a role in the recovery from surgical wounds.

\section{Statement of Ethics}

The patient provided consent to inclusion in this case report and publication of the data.

\section{Disclosure Statement}

There is no financial conflict of interest; however, the author of the paper is the patient.

\section{References}

1 Stechmiller JK. Understanding the role of nutrition and wound healing. Nutr Clin Pract. 2010 Feb;25(1):61-8.

2 Skeie E, Koch AM, Harthug S, Fosse U, Sygnestveit K, Nilsen RM, et al. A positive association between nutritional risk and the incidence of surgical site infections: A hospital-based register study. PLoS One. 2018 May;13(5):e0197344.

3 Campos AC, Groth AK, Branco AB. Assessment and nutritional aspects of wound healing. Curr Opin Clin Nutr Metab Care. 2008 May;11(3):281-8.

4 MacKay D, Miller AL. Nutritional support for wound healing. Altern Med Rev. 2003 Nov;8(4):359-77.

5 Breslow RA, Hallfrisch J, Guy DG, Crawley B, Goldberg AP. The importance of dietary protein in healing pressure ulcers. J Am Geriatr Soc. 1993 Apr;41(4):357-62.

6 Gruen D. Wound healing and nutrition: going beyond dressings with a balanced care plan. J Am Col Certif Wound Spec. 2010 Feb;2(3):46-9.

7 Armstrong DG, Hanft JR, Driver VR, Smith AP, Lazaro-Martinez JL, Reyzelman AM, et al.; Diabetic Foot Nutrition Study Group. Effect of oral nutritional supplementation on wound healing in diabetic foot ulcers: a prospective randomized controlled trial. Diabet Med. 2014 Sep;31(9):1069-77.

8 Williams JZ, Abumrad N, Barbul A. Effect of a specialized amino acid mixture on human collagen deposition. Ann Surg. 2002 Sep;236(3):369-74; discussion 374-5.

9 Zhou M, Martindale RG. Arginine in the critical care setting. J Nutr. 2007 Jun;137(6 Suppl 2):1687S-92S.

10 Collins N. Arginine and wound healing: a case study. Adv Skin Wound Care. 2004 Mar;17(2):59-60.

11 Neyens JC, Cereda E, Meijer EP, Lindholm C, Schols JM. Arginine-enriched oral nutritional supplementation in the treatment of pressure ulcers: a literature review. Wound Medicine. 2017;16:46-51.

12 Schols JM, Heyman H, Meijer EP. Nutritional support in the treatment and prevention of pressure ulcers: an overview of studies with an arginine enriched oral nutritional supplement. J Tissue Viability. 2009 Aug;18(3):72-9.

13 Cawood AL, Elia M, Stratton RJ. Systematic review and meta-analysis of the effects of high protein oral nutritional supplements. Ageing Res Rev. 2012 Apr;11(2):278-96. 


\section{Case Reports in Clinical Nutrition}

\begin{tabular}{|c|c|}
\hline \multicolumn{2}{|c|}{ Case Rep Clin Nutr 2018;1:1-7 } \\
\hline DOI: $10.1159 / 000494666$ & $\begin{array}{l}\text { (c) } 2018 \text { The Author(s). Published by S. Karger AG, Basel } \\
\text { www.karger.com/crc }\end{array}$ \\
\hline
\end{tabular}

Hicks-Roof: Arginine-Enriched Oral Nutrition Supplement for Wound Healing

14 Cereda E, Klersy C, Andreola M, Pisati R, Schols JM, Caccialanza R, et al.; OligoElement Sore Trial (OEST) Study Group. Cost-effectiveness of a disease-specific oral nutritional support for pressure ulcer healing. Clin Nutr. 2017 Feb;36(1):246-52.

15 Centers for Disease Control and Prevention. Births - Method of Delivery. 2017; https://www.cdc.gov/nchs/ fastats/delivery.htm.

16 Childbirth Connections. Cesarean Birth Trends. National Partnership for Women \& Families; 2017.

17 The Cost of Having a Baby in the United States. Truven, 2013.

18 Kealy MA, Small RE, Liamputtong P. Recovery after caesarean birth: a qualitative study of women's accounts in Victoria, Australia. BMC Pregnancy Childbirth. 2010 Aug;10(1):47.

19 Lazarus GS, Cooper DM, Knighton DR, Percoraro RE, Rodeheaver G, Robson MC. Definitions and guidelines for assessment of wounds and evaluation of healing. Wound Repair Regen. 1994 Jul;2(3):165-70.

20 Fearmonti R, Bond J, Erdmann D, Levinson H. A review of scar scales and scar measuring devices. Eplasty. 2010 Jun;10:e43.

21 Vercelli S, Ferriero G, Sartorio F, Cisari C, Bravini E. Clinimetric properties and clinical utility in rehabilitation of postsurgical scar rating scales: a systematic review. Int J Rehabil Res. 2015 Dec;38(4):27986.

22 Singer AJ, Arora B, Dagum A, Valentine S, Hollander JE. Development and validation of a novel scar evaluation scale. Plast Reconstr Surg. 2007 Dec;120(7):1892-7.

23 Rousseau JA, Girard K, Turcot-Lemay L, Thomas N. A randomized study comparing skin closure in cesarean sections: staples vs subcuticular sutures. Am J Obstet Gynecol. 2009 Mar;200(3):265.e1-4.

24 Sethukumar P, Ly D, Awad Z, Tolley NS. Scar satisfaction and body image in thyroidectomy patients: prospective study in a tertiary referral centre. J Laryngol Otol. 2018 Jan;132(1):60-7.

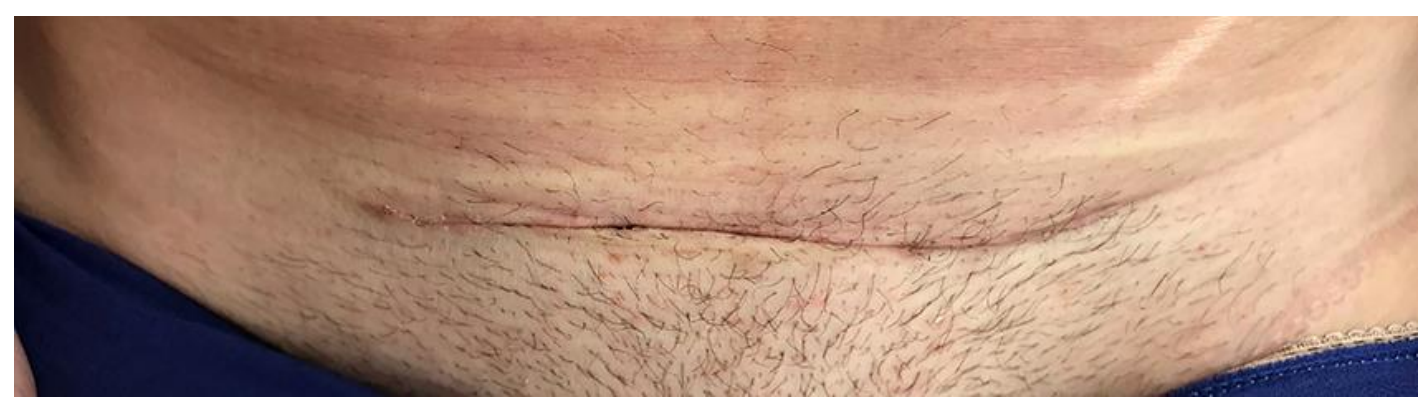

Fig. 1. Scar assessment 2 weeks postpartum. 
Hicks-Roof: Arginine-Enriched Oral Nutrition Supplement for Wound Healing

Table 1. Anthropometric measurements

\begin{tabular}{llllll}
\hline & $\begin{array}{l}\text { Pre- } \\
\text { pregnancy }\end{array}$ & $\begin{array}{l}\text { 1st pregnancy } \\
\text { visit (week 9) }\end{array}$ & $\begin{array}{l}\text { Midpregnancy } \\
\text { visit (week 20) }\end{array}$ & $\begin{array}{l}\text { Delivery } \\
\text { date }\end{array}$ & $\begin{array}{l}\text { 2 weeks } \\
\text { postpartum }\end{array}$ \\
\hline $\begin{array}{l}\text { Weight, kg } \\
\text { BMI, kg/m² }\end{array}$ & 62.3 & 63.6 & 68.6 & 79.1 & 71.8 \\
$\begin{array}{l}\text { Systolic/diastolic blood } \\
\text { pressure, mm Hg }\end{array}$ & 23.5 & 24 & 25.9 & 29.9 & 27.1 \\
\hline
\end{tabular}

Table 2. Stony Brook Scar Evaluation Scale

\begin{tabular}{lll}
\hline Attribute & Scar characteristic & Score \\
\hline Width & $>2 \mathrm{~mm}$ & 0 \\
& $\leq 2 \mathbf{~ m m}$ & $\mathbf{1}$ \\
\hline Height & elevated/depressed compared to surrounding skin & 0 \\
& flat & $\mathbf{1}$ \\
\hline Color & darker than surrounding area & 0 \\
& same or lighter than surrounding area & $\mathbf{1}$ \\
\hline Hatch marks & present & 0 \\
\hline Overall appearance & poor & $\mathbf{1}$ \\
\hline Total & good & 0 \\
\hline
\end{tabular}

Bold indicates selection by physician for each category. 


\section{Case Reports in Clinical Nutrition}

Case Rep Clin Nutr 2018;1:1-7

DOI: $10.1159 / 000494666$

(c)

(c) 2018 The Author(s). Published by S. Karger AG, Basel www.karger.com/crc

Hicks-Roof: Arginine-Enriched Oral Nutrition Supplement for Wound Healing

Table 3. Manchester Scar Scale

\begin{tabular}{|c|c|c|}
\hline Attribute & Scar characteristic & Score \\
\hline \multirow[t]{4}{*}{ Color } & perfect & 1 \\
\hline & slight mismatch & 2 \\
\hline & obvious mismatch & 3 \\
\hline & gross mismatch & 4 \\
\hline \multirow{2}{*}{$\begin{array}{l}\text { Matte versus } \\
\text { shiny }\end{array}$} & matte & 1 \\
\hline & shiny & 2 \\
\hline \multirow[t]{4}{*}{ Contour } & flush with surrounding skin & 1 \\
\hline & slightly proud/indented & 2 \\
\hline & hypertrophic & 3 \\
\hline & keloid & 4 \\
\hline \multirow[t]{4}{*}{ Distortion } & none & 1 \\
\hline & mild & 2 \\
\hline & moderate & 3 \\
\hline & severe & 4 \\
\hline \multirow[t]{4}{*}{ Texture } & normal & 1 \\
\hline & just palpable & 2 \\
\hline & firm & 3 \\
\hline & hard & 4 \\
\hline Total & & 8 \\
\hline
\end{tabular}

